\title{
Education Of Health Cadres with Methods Emotional Demonstration (Emo Demo) - Asi Only Enough
}

\author{
Niluh Nita Silfia, Artika Dewie ${ }^{\text {a), }}$ and Asri Widyayanti \\ Prodi DIII Kebidanan Jurusan Kebidanan Poltekkes Kemenkes Palu, Palu, Indonesia \\ ${ }^{a}$ Corresponding author : dewieartika@gmail.com
}

\begin{abstract}
The Emo Demo strategy is the arrangement of advising with the procedure of conveying messages that are given in a straightforward, fun and contacting feeling, animating the objective of directing to effortlessly recollect the message given. As one of the directing procedures with respect to elite breastfeeding, instruction for wellbeing units is done on the Emo Demo-ASI Only Enough technique which intends to build the information and abilities of wellbeing frameworks in the Dolo Health Center working region in giving advising utilizing the Emo Demo-ASI just Enough strategy. This people group administration is through giving materials and exhibits to sharpen the abilities of wellbeing frameworks who are engaged with advising exercises, particularly about elite breastfeeding as one of the anticipation of hindering in the workspace of the Dolo Health Center. This movement is completed in gatherings, starting and finishing with a pre-test and post-test. The aftereffects of this review show an expansion in information on most of wellbeing units as much as $72.5 \%$. With a restricted time, after an exhibition and practice of the abilities of the Emo demo-ASI technique was adequate, from the past $100 \%$ incompetent, it was seen that few wellbeing frameworks had the option to rehearse the emotional demo-ASI strategy, just $10 \%$ were talented.
\end{abstract}

Keywords : Emo Demo, exclusive breastfeeding, health cadres, counseling, demonstration

\section{INTRODUCTION}

Mother's milk (ASI) is the initial nutrition for infants in which it contains all the intake needed by infants, ranging from immune substances that protect infants from infection, vitamins, minerals and other substances needed by infants. Data shows that there are 2 million babies out of 136 million babies born per year who are not exclusively breastfed (Gupta et al., 2013). Mentioned by the World Health Organization (WHO), every year around 800,000 children in the world can live the first year of life well because of breast milk compared to children who are given formula milk. The children were given colostrum since 4 hours after birth and continued with full breast milk until the age of two years (Unicef, 2018).

Globally, WHO targets exclusive breastfeeding of at least $50 \%$ in 2025 , from $38 \%$ in 2017. The coverage of exclusive breastfeeding in Indonesia until 2019 has increased. In 2017 it was $54,0 \%$, in 2018 it was 67,74\% and in 2019 it was 68,74\% (Kementerian Kesehatan Republik Indonesia, 2020). Exclusive breastfeeding coverage in Central Sulawesi Province in 2017 - 2019 shows a fluctuating number, in 2017 it was $56.6 \%$ increasing to $57.7 \%$ in 2018 . Exclusive breastfeeding coverage decreased in 2019 to 54,7\% In 2019, Sigi Regency occupies the sixth position out of thirteen Cities/Regencies in Central Sulawesi Province with 56,1\% exclusive breastfeeding coverage (Dinas Kesehatan Provinsi Sulawesi Tengah, 2019).

Among the features of breast milk, it is also mentioned that breast milk contains high levels of calcium and antibodies and is easily absorbed by the baby's body so that the baby's bone formation can be optimal. Under these conditions, of course, it can be concluded that exclusive breastfeeding can reduce the risk of stunting (Latifah et al., 2020). Central Sulawesi Province ranks tenth for the proportion of stunting (TB/U) with a stunting rate of $31.26 \%$ in children under five. Sigi is a district with a number Toddler Nutritional Statusprevalence Stunting third highest prevalence infant nutritional status issues, namely Stunting 24,6\% (Dinas Kesehatan Provinsi Sulawesi Tengah, 2019). In 2020 the Sigi district government through the Sigi Regent's 
Decree Number: 444-185 of 2020 set 10 Convergence Focus Locations (LOKUS) for the acceleration ofreduction stunting in 2021. One of the ten convergence loci for the acceleration ofreduction stunting is in the work area of the Dolo Health Center. (Dinas Kesehatan Kabupaten Sigi, 2020).

To increase the coverage of exclusive breastfeeding which in turn will reduce the risk of stunting, it is necessary to strengthen what is done, including the implementation of breastfeeding counseling and increasing collaboration with health cadres as one of the drivers in the community in the health sector. Health cadres can play an active role in providing exclusive breastfeeding counseling to target communities including pregnant women, breastfeeding mothers and increasing support and the role of families in providing exclusive breastfeeding. To prevent the provision of health education counseling or education being monotonous and ultimately eliminating the desire of the target community to participate, it is necessary to innovate ways of counseling or providing health education education that can be carried out by health cadres. Quoted from Notoatmodjo, the selection of health education or counseling methods that are suitable for the target can increase the success of the health education or counseling provided (Notoatmodjo, 2012).

The Global Alliance for Improved Nutrition (GAIN) developed a public education technique called the Emotional Demonstration method or the Emo Demo method. By referring to the Behavior Centered Design (BCD) theory, this theory has the principle that behavior change can occur due to receiving a response to something new, interesting, challenging and even surprising (Laxminarayan et al., 2006). The Emo Demo method is the provision of counseling with imaginative and participatory techniques. The delivery of the message is given in a simple, fun and touching emotion, stimulating the target of the counseling to easily remember the message given in the counseling in the hope of changing behavior in the field of public health. The activity is very simple, the time needed for counseling with the emo demo technique is only about 15-20 minutes. The Emo-Demo method consists of several themes targeting mothers, toddlers and their families. From these themes, counseling for exclusive breastfeeding is called Emo Demo-ASI only Enough. (Global Alliance for Improved Nutrition (GAIN), 2014).

Health cadres in the working area of the Dolo Health Center, Sigi Regency are cadres who participate and communicate actively with pregnant and lactating mothers and families in motivating exclusive breastfeeding. However, they have never received education on providing counseling using the emo demo-ASI method. Based on the things mentioned above, this community service activity is carried out with the aim of increasing the knowledge and skills of health cadres in implementing counseling activities in the Dolo Health Center work area, especially using the Emo Demo-ASI method. By increasing the knowledge and skills of health cadres about this method, it is hoped that later health cadres can apply the Emo Demo-ASI method to the target community at the posyandu.

\section{METHOD}

Education of health cadres on the emo-demo-ASI method is sufficient. It is divided into two activities. The first activity is to provide knowledge material about Emo demo-ASI is sufficient and followed by demonstrations to improve the skills of health cadres in the implementation of the emo-demo-ASI method. This activity took place in the meeting room of the Dolo Health Center, Sigi Regency in April 2021. The participants of this community service activity were 40 health cadres in the Dolo Health Center working area and were divided into five groups of eight people each. These activities are carried out in small groups in turns for the effectiveness of receiving materials and demonstrations and practices carried out by group members.

The activity began with filling out an initial questionnaire (pre-test) relating to the knowledge of health cadres about exclusive breastfeeding as an effort to prevent stunting and observing skills about the Emo Demo-ASI Method. The provision of materials and information about Exclusive Breastfeeding by the community service team is the next activity to be carried out. Connected with demonstration activities for the emo-demo-ASI Only Enough for the Training of 
Trainers (TOT). The demonstration activity uses several types of tools and materials, namely cooking oil, liquid milk, several small and large sized objects, for example: beads, candlenuts, marbles, bekel balls, kluwek, ping pong balls, toy eggs, tennis balls, 4 cards Baby's stomach, measuring cup and plastic water cup (Figure 1). Module Emo demo- ASI Only Enough which was created by the community service team and the TOT Emo Demo is also used in this community service activity. The module was distributed to every health cadre who was present, making it easier for the cadres to understand the contents of the Emo Demo-ASI training. This activity ended with the measurement of knowledge about exclusive breastfeeding as an effort to prevent stunting and the skills of health cadres on the Emo Demo-ASI only (post test) using a questionnaire and observation of the practice of skills in performing emo-breastfeeding was sufficient.

\section{RESULTS}

Performed community service at Puskesmas working area Dolo Sigi received a positive response from the target audience is health volunteers (Figure 2). In addition to increasing knowledge, health cadres are also guided to conduct counseling using the emo-demo-ASI method, which is sufficient and correct. Enthusiasm can also be seen from the activeness of health cadres in participating in the demonstration of the emo demo-ASI method with the community service team (Figure 3 ).

This community service activity also shows the characteristics of health cadres in the working area of the Dolo Health Center, Sigi Regency (Table 1). 50 years old as many as 26 people (65\%) and almost all of them have high school education as many as 34 people (85\%).

From the value of the questionnaires distributed before and after (pretest and posttest) the provision of materials or concepts regarding the Emo demo-ASI method was sufficient (Table 2), it can be seen that before being given concept material, out of 40 health cadres, almost all health cadres had less knowledge, namely 35 people (87.5\%). But after being given enough material about the concept of the Emo demo-ASI method, there was an increase in knowledge. It can be seen that most of the health cadres have good knowledge of 29 people $(72.5 \%)$.

From the assessment before and after (pretest and posttest) demonstration of the Emo-demoASI method was sufficient (Table 3), it can be seen that before the demonstration, out of 40 health cadres, all health cadres were less skilled, namely 40 people (100\%). However, after being given a demonstration about the Emo demo-ASI method, it was seen that a small number of health cadres were able to practice the emo-demo-ASI method quite skillfully, as many as 4 people (10\%).

\section{DISCUSSION}

Method Emotional Demonstration or also called Emo-Demo is a communication approach technique with the expectation of innovative behavior change and proven effective in improving maternal behavior related to infant and child feeding. Interviews that have been conducted with mothers who have babies. Before using Emo-Demo, counseling at the Posyandu tended to be boring because the counseling participants only listened passively. But when using the EmoDemo method, counseling participants can participate because there are fun games, so that health messages are more easily conveyed. An evaluation study conducted by the Global Alliance for Improved Nutrition (GAIN) from 2015-2017 on about 3,000 mothers with children under two years old in East Java Province, it was seen that the effectiveness of counseling using Emo-Demo increased exclusive breastfeeding by $66 \%$ compared to the one-way extension method (55\%) (Global Alliance for Improved Nutrition (GAIN), 2014).

Health cadres who have a function as community empowerment and have a social spirit are expected to help health workers to be able to implement healthy living behaviors in the community (Susanto et al., 2017). As essential personnel needed in every posyandu activity, 
health cadres should have the ability to provide education or counseling to target communities as needed.

Quoting from Notoatmodjo, Knowledge is the basis of humans to act or do something. Knowledge is influenced by many factors, such as age, education, socio-culture, environment, economy and experience. With good knowledge, good behavior can be formed and last longer (Dewie, 2021). Kurrachman, 2003 in Triyanti stated that providing education with lecture and discussion methods, followed by demonstrations and practice can improve skills. Especially if these skills continue to be applied (Triyanti et al., 2017). In this case, frequent counseling using the emo-demo-ASI method is sufficient, it will make health cadres more proficient in carrying out these activities and the target community understands and is willing to give exclusive breastfeeding to their babies.

Exclusive breastfeeding given to infants without additional formula milk or any food can meet the nutritional needs of infants and can prevent stunting (Cahya Rosida et al., 2020). Several studies are in line with this statement, including research in Pinrang Regency which states that there is a significant relationship between exclusive breastfeeding and stunting (Suriana, Haniarti, 2021). Likewise, research conducted in Central Lampung (Rilyani et al., 2021). It is contrary to research in Bantul Regency which did not find a significant relationship between exclusive breastfeeding and stunting (Suwartini et al., 2020).

\section{CONCLUSIONS AND RECOMMENDATIONS}

Various theories suggest that exclusive breastfeeding can be one way to reduce the risk of stunting. Exclusive breastfeeding for babies and continued until the age of two years will create healthy generations in the future. By teaching the Emo-demo- ASI Only Enough to health cadres is one way that can be done to invite mothers who have babies and toddlers to be more aware of the importance of exclusive breastfeeding.

Health cadres look active and enthusiastic in participating in this community service activity. As evidenced by the limited time, there are already health cadres who are able to practice the emo demo-ASI method quite well. Activities that are material giving and demonstrations like this should be carried out regularly and continuously because most health cadres have high school education and have other activities besides being health cadres.

\section{ACKNOWLEDGMENTS}

Delivered to the Head of the Dolo Health Center, who has allowed the community service team to carry out this activity, the Training of Trainers (TOT) for the Emo-demo-ASI method is sufficient and the Director of Poltekkes, Ministry of Health, Palu, who allows this activity to be carried out and provides benefits for people many

\section{REFERENCES}

Cahya Rosida, D. A., Nuraini, I., \& Rihardini, T. (2020). Usaha untuk Meningkatkan Cakupan ASI Eksklusif dengan Pendekatan Emotional Demonstration "ASI Saja Cukup." Dedication: Jurnal Pengabdian Masyarakat, 4(1), 25-32. https://doi.org/10.31537/dedication.v4i1.290

Dewie, A. (2021). Pengetahuan dan Sikap tentang tanda bahaya kehamilan berhubungan dengan pemanfaatan buku KIA. Jambi Medical Journal, 9(Juni), 138-146. https://doi.org/https://doi.org/10.24198/dharmakarya.v8i3.20726

dinas kesehatan kabupaten sigi. (2020). analisis situasi perkecamatan kabupaten sigi.

Dinas Kesehatan Provinsi Sulawesi Tengah. (2019). Profil Kesehatan Provinsi Sulawesi Tengah Tahun 2019. In Dinas Kesehatan Provinsi Sulawesi Tengah.

Global Alliance for Improved Nutrition (GAIN). (2014). Konsep Emo Demo. https://emodemo.org/about/concept-theory

Gupta, A., Dadhich, J. P., \& Suri, S. (2013). How Can Global Rates of Exclusive Breastfeeding for 
the First 6 Months Be Enhanced? ICAN : Infant, Child, and Adolescent Nutrition, 5(3), 133140. https://doi.org/10.1177/1941406413480389

Kementerian Kesehatan Republik Indonesia. (2020). Profil Kesehatan Indonesia Tahun 2019. In Kementerian Kesehatan Republik Indonesia. https://doi.org/10.5005/jp/books/11257_5

Latifah, A. M., Purwanti, L. E., \& Sukamto, F. I. (2020). Hubungan Pemberian ASI Eksklusif Dengan Kejadian Stunting Pada Balita 1-5 Tahun. Health Sciences Journal, 4(1), 1-12. http://studentjournal.umpo.ac.id/index.php/HSJ/article/view/131\%0Ahttp://jurnal.umt.ac.id/ind ex.php/jkft/article/view/1018

Laxminarayan, R., Chow, J., \& Shahid-salles, S. A. (2006). Intervention Cost-Effectiveness: Overview of Main Messages. In Disease Control Priorities in Developing Countries (2nd Edition) (Issue March, pp. 35-86). https://doi.org/10.1596/978-0-8213-6179-5/chpt-2

Notoatmodjo, S. (2012). Promosi Kesehatan dan Perilaku (Edisi Revisi). Rineka Cipta.

Rilyani, R., Wandini, R., \& Lestari, W. D. (2021). Pemberian ASI Eksklusif dengan Kejadian Stunting pada Balita. JIKSH: Jurnal IImiah Kesehatan Sandi Husada, 10(1), 1-6. https://akper-sandikarsa.e-journal.id/JIKSH/article/view/489/351

Suriana, Haniarti, R. A. D. P. (2021). The Weight of Birth and Exclusif Breastfeeding for Stunting in Infants in Cappakalla, Mattiro Sompe, Pinrang. Jurnal IImiah Manusia Dan Kesehatan, 4(2). http://jurnal.umpar.ac.id/index.php/makes/article/view/561/716

Susanto, F., Claramita, M., \& Handayani, S. (2017). Peran kader posyandu dalam pemberdayaan masyarakat Bintan. BKM Journal of Community Medicine and Public Health, 33(1), 13-18. https://doi.org/https://doi.org/10.22146/bkm.11911

Suwartini, I., Hati, F. S., \& Paramashanti, B. A. (2020). Riwayat Asi Eksklusif Dan Stunting Pada Anak Usia 24-59 Bulan Di Kecamatan Pajangan Dan Pleret, Kabupaten Bantul. Media Gizi Pangan, 27(2), 37-43. https://doi.org/10.32382/mgp.v27i2.1642

Triyanti, M., Widagdo, L., \& BM, S. (2017). Peningkatan Pengetahuan dan Ketrampilan Kader Pemantauan Tumbuh Kembang Balita di Posyandu dengan Metode BBM dan Mind Mapping (MM). Jurnal Promosi Kesehatan Indonesia, 12(2), 265-277.

Unicef. (2018). Breastfeeding A Mother's Gift, for Every Child. In Unicef for Every Child. 


\section{APPENDIX}

Table 1. Frequency Distribution of Health Cadre Characteristics in the Working area of the Dolo Health Center, Sigi Regency

\begin{tabular}{ccc}
\hline Characteristic & F & $\%$ \\
\hline Ages & 14 & 35 \\
20-30 Years old & 26 & 65 \\
31-50 Years old & & \\
Education & 6 & 15 \\
Primary-Middle & 34 & 85 \\
School & 40 & 100,0 \\
High School & &
\end{tabular}

Table 2. Distribution of Knowledge Frequency of Health Cadres who participated in the Emo Demo- ASI Only Enough in the Work Area of the Dolo Health Center, Sigi Regency

\begin{tabular}{lcccc}
\multirow{2}{*}{ Knowledge } & \multicolumn{3}{c}{ Emo Demo- ASI Only Enough } \\
\cline { 2 - 5 } & \multicolumn{3}{c}{ Before } & \multicolumn{3}{c}{ After } \\
\cline { 2 - 5 } & $\mathbf{n}$ & \% & $\mathbf{n}$ & \% \\
\hline Good & 5 & 12,5 & 29 & 72,5 \\
Not good & 35 & 87,5 & 11 & 27,5 \\
\hline Total & 40 & 100 & 40 & 100 \\
\hline
\end{tabular}

Tabel 3. Distribution of Skills Frequency of Health Cadres who participated in the Emo Demo- ASI Only Enough in the Work Area of the Dolo Health Center, Sigi Regency

\begin{tabular}{lcccc}
\hline \multirow{2}{*}{ Skills } & \multicolumn{3}{c}{ Emo Demo-ASI Only Enough } \\
\cline { 2 - 5 } & \multicolumn{2}{c}{ Before } & \multicolumn{2}{c}{ Before } \\
\cline { 2 - 5 } & $\mathbf{n}$ & $\%$ & $\mathbf{n}$ & $\%$ \\
\hline Skilled & 0 & 0 & 4 & 10 \\
Unskilled & 40 & 100 & 36 & 90 \\
\hline Total & 40 & 100 & 40 & 100 \\
\hline
\end{tabular}

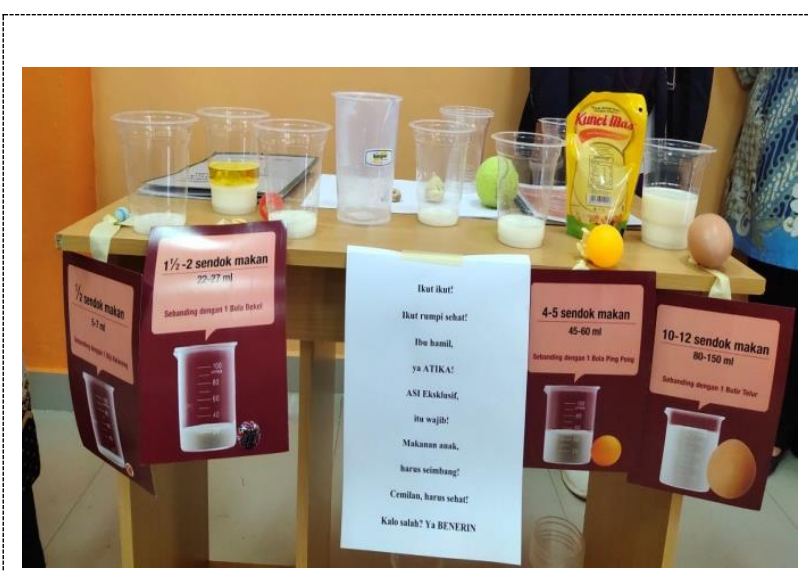

Figure 1. Practice Tools and Materials

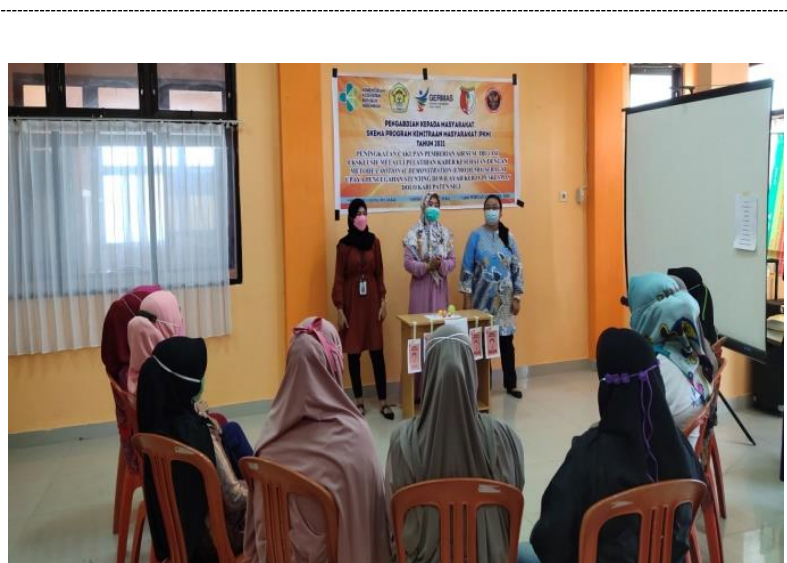

Figure 2. Just giving Material Emo demo- ASI 


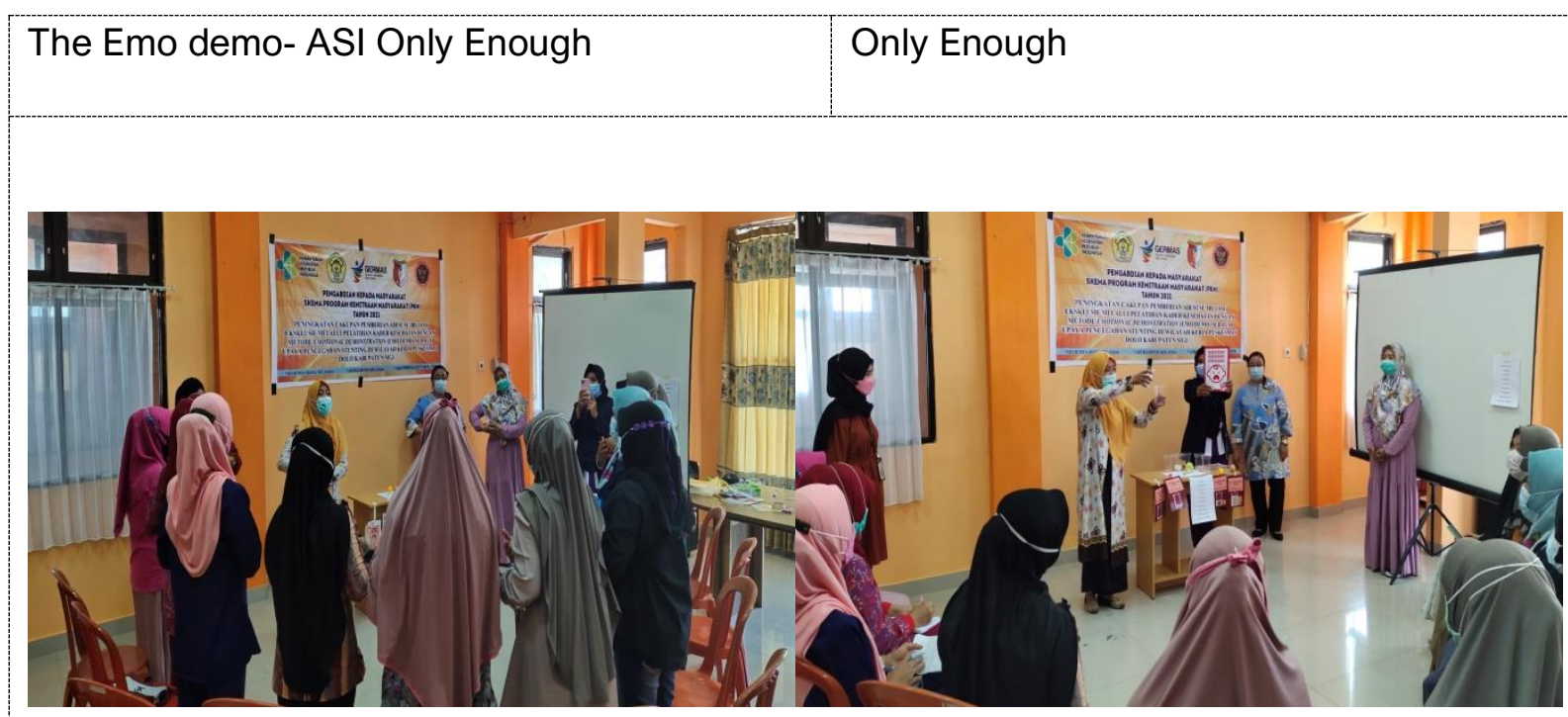

Figure 3. Enthusiasm of health cadres in participating in activities 